inextricably linked to the means of its implementation, which include mobile phones, smartphones, personal digital assistants, tablets. The basic characteristics that are inherent in the process of mobile learning are considered: continuity, flexibility, orientation on pupils, and freedom in location choice. In this article mobile learning is compared with other modern pedagogical technologies, such as blended learning, distance learning, ICT-based learning by such means of communication, creation and delivery of training material, skills development, knowledge control, level of learning process continuity. The place of mobile learning in the educational process of general secondary education institutions is determined. The general advantages of mobile learning (continuous access to the educational environment anytime and anywhere, organization of online collaboration, positive impact on the pupils' motivation) and organizational difficulties (availability of material and technical background and pupils' skills) are considered. The article presents the results of a survey about usage mobile learning state in general secondary education which present that most pupils have the opportunity to use mobile technology in the classroom and have a positive attitude to the use of mobile devices during the learning process.

Keywords: blended learning, distance learning, ICT-based learning (e-learning), mobile learning (mlearning).

DOI 10.31392/NPU-nc.series 2.2020.22(29).25

УДК 378.147:004.9

Ірина Вікторівна Вакуленко

аспірантка

Національний педагогічний університет імені М.П. Драгоманова, Україна

ORCID: 0000-0002-0768-990X

vakulenko.iryna@gmail.com

\title{
УПРАВЛІННЯ САМОСТІЙНОЮ РОБОТОЮ МАЙБУТНІХ ВЧИТЕЛІВ В ПРОЦЕСІ НАВЧАННЯ ІНФОРМАТИКИ З ВИКОРИСТАННЯМ СИСТЕМ КОМП'ЮТЕРНОЇ МАТЕМАТИКИ
}

\begin{abstract}
Анотація. Самостійна робота студентів є основною та однією 3 важливих форм організації освітнього процесу у вищій школі, а тому й потребує особливої уваги. 3 іншого боку, підготовка фахівця, здатного до самостійного професійного самовдосконалення впродовж життя є вимогою сучасного швидкозмінного інформатизованого суспільства. Одним 3 методичних напрямів вивчення самостійної роботи студентів є дослідження питань управління нею. Адже характерними ознаками самостійної роботи студентів $\epsilon$ їх самостійність за умови опосередкованого спрямування, оперативного та систематичного контролю, навчально-методичного супроводу з боку викладача. Стаття присвячена дослідженню дидактичних можливостей використання програмних засобів комп'ютерної математики стосовно управління самостійною роботою майбутніх вчителів в процесі навчання інформатики, зокрема чисельних методів. Для аналізу було обрано наступні безкоштовні програмні засоби, що отримали високу науково-методичну популярність, як серед вітчизняних так $\mathrm{i}$ закордонних дослідників: програми-розв'язувачі Gran1, Gran-2D; обчислювальна система знань Wolfram|Alpha, хмаро орієнтована система комп'ютерної математики SageMathCloud. Окрім того, розглянуто використання мови програмуванням Python, що вважається простою і легкою для навчання та містить потужні засоби для виконання наукових та інженерних розрахунків. Подано основні напрямки застосування в курсі чисельних методів розглянутих програмних засобів, а також методи, що покладені в основу виконання деяких команд програмних засобів. Особливості управління самостійною роботою студентів розглянуто на прикладі навчання курсу чисельних методів математики, який відрізняється сильними міжпредметними зв'язками, а також навчання якого сприяє розвитку творчо-дослідницьких умінь майбутніх вчителів. Наскрізно розглянуто приклад розв'язування задачі інтерполювання функції, як одного 3 найбільш розповсюджених методів для отримання поліноміальних наближень в курсі чисельних методів. Запропоновані програмні засоби можуть використовуватись на різних етапах управління самостійною роботою майбутніх вчителів в процесі навчання чисельних методів.
\end{abstract}

Ключові слова: управління самостійною роботою студентів, система комп'ютерної математики, чисельні методи, Gran1, Gran-2D, Wolfram|Alpha, SageMathCloud, Python.

Вступ. Самостійна робота студентів $є$ вагомою складовою підготовки сучасного фахівця, завдяки якій забезпечується формування самостійної особистості, здатної неперервно вдосконалювати свої професійні знання в швидкозмінному високотехнологічному суспільстві, а також глибоко пізнавати 
навчальний матеріал, який, як відомо, найкраще усвідомлюється 3 докладанням власних зусиль. Адже, як зазначав в 80-х роках минулого сторіччя американський соціолог та письменник Е. Тоффлер (A. Toffler), «завтра неосвіченою буде не та людина, яка не вміє писати та читати, а та, яка не навчилася вчитися» [1]. На сьогодні самостійне навчання на основі достатнього запасу знань $\epsilon$ частиною нашого повсякденного існування. Завдання педагога в такому разі полягає в тому, щоб надати студентам можливість навчитися вчитися і бути відповідальним за власне навчання, а також створити ефективне навчальне середовище, завдяки якому студенти могли б активно брати участь в освітньому процесі.

Відтак, перед науково-педагогічними працівниками закладів вищої освіти постають проблеми ефективного управління самостійною роботою студентів, які можна розв'язати, використовуючи сучасні інформаційно-комунікаційні технології (IКT), застосування яких має значний дидактичний потенціал для диференціації та індивідуалізації навчання, оперативного контролю та регулювання навчально-пізнавальної діяльності, а також для посилення інтересу студентів до навчального матеріалу та розвитку їх дослідницьких вмінь та навичок самоосвіти.

Особливої актуальності зазначені проблеми набувають в процесі навчання так званих інформатично-математичних дисциплін, де засоби IКТ виступають, окрім того, потужним «помічником» в процесі розв'язування задач, використання яких дозволяє швидко виконувати потрібні обчислення та графічні побудови, унаочнювати та ілюструвати процес розв'язування задач, випробовувати гіпотези та методи їх підтвердження чи спростування.

Аналіз останніх досліджень і публікацій. Самостійна робота студентів є ключовою складовою вищої освіти, однією з завжди актуальних та багатогранних тем, саме тому у вітчизняній та зарубіжній літературі публікується значна кількість дослідницьких робіт та наукових статей, в яких розглядаються ті чи інші іiі аспекти. Так до висвітлення наукових та методологічних засад самостійної роботи студентів долучилися Дж. Броуд (J. Broad), М. Букерц (M. Boekaerts), В. К. Буряк,

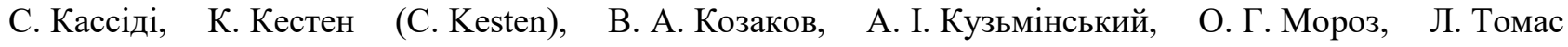
(L. Thomas), M. Хілі (M. Healey), К. Хокінгс (C. Hockings) та інші.

Однак всі дослідники сходяться на тому, що ефективній самостійній роботі студентів притаманна самостійність студентів з докладанням власних зусиль щодо встановлення цілей, вибору стратегій навчання, підтримки уваги, виконання та контролю власної навчальної діяльності без безпосередньої участі педагога, але за умови його методичного супроводу, опосередкованого спрямування, оперативного контролю 3 використанням відповідного навчального середовища та навчальних ресурсів. Тобто за умови педагогічного управління з боку викладача, яке сприяє активній участі студентів в освітньому процесі.

Актуальною залишається думка П. Найта (P. Knight) [2], с. 35], який стверджував, що самостійність студентів - це мета, а не вихідний стан; для розвитку самостійності потрібно цілеспрямовано формувати майстерність щодо самостійної пізнавальної діяльності за допомогою сприятливої структури; самостійність - це не відсутність управління, а результат процесу навчання, коли студенти працюють за такими інструкціями (настановами), які вони бажають отримати, досягнення чого потребує ретельного планування та управляючих впливів з боку педагогів.

Тому одним 3 методичних напрямів вивчення самостійної роботи студентів $\epsilon$ дослідження питань управління нею, адже процес навчання як процес управління навчально-пізнавальною діяльністю студентів розглядався багатьма педагогами та психологами: С. І. Архангельським, Т. О. Дмитренко, І. А. Зимньою, Ю. І. Машбицем, . І. Підкасистим, Н. Ф. Тализіною, Л. М. Фрідманом, Т. М. Хлєбніковою, В. А. Якуніним, К. В. Яресько та іншими.

Стрімкий розвиток засобів інформатизації різних галузей людської діяльності призвів до впровадження інформаційно-комунікаційних технологій (IКТ) в педагогічну практику в тому числі і до управління самостійною роботою студентів. Зокрема, Л. І. Білоусова, Л. С. Колгатіна та О. Г. Колгатін [3] для управління самостійною роботою студентів пропонують методи організації навчальних досліджень 3 використанням комп'ютерних моделей в середовищі Mathcad. B своїх роботах [4], [5] Ю. С. Рамський та М. В. Рафальська для реалізації творчо-дослідницької самостійної діяльності студентів в галузі математичного моделювання в процесі навчання методів обчислень використовують програмні засоби загального (Excel) та навчального (Gran1, Gran-2D) призначення, а також систему комп'ютерної математики (Maple).

Дослідженню використаня хмаро орієнтованого середовища SageMathCloud як засобу навчання математичних та інформатичних дисциплін присвячували свої роботи М. Вуорінен (M. Vuorinen) та Л. Руотсалайнен (L. Ruotsalainen) [6], М. В. Попель [7], С. О. Семеріков та його учні [8]. Ряд авторів присвячували свої роботи розгляду дидактичних можливостей використання системи знань Wolfram|Alpha в процесі навчання математичних дисциплін: Ю. В. Горошко, П. Нечесал (P. Nečesal) та Я. Поспішил (J. Pospíśil) [9], Д. А. Покришень, Ю. В. Триус та інші. Поширенню та потужному 
навчально-методичному супроводу українських педагогічних програмних засобів Gran1, Gran-2D в процесі навчання присвятили свої роботи їх розробники Ю. В. Горошко, М. І. Жалдак [10] та інші, в тому числі впровадженню на їх основі методичних систем навчання, що передбачає, зокрема, i комп'ютерно орієнтоване управління самостійною роботою студентів.

Таким чином, на сьогодні педагоги в своєму арсеналі мають достатню кількість комп'ютерно орієнтованих засобів управління самостійною роботою студентів, однак надалі залишається відкритим питання подальшого їх дослідження щодо особливостей застосування та методичного супроводу в умовах постійного їх оновлення та вдосконалення.

Мета написання статті полягає в дослідженні дидактичних можливостей використання засобів комп’ютерної математики стосовно управління самостійною роботою майбутніх вчителів в процесі навчання інформатично-математичних дисциплін, зокрема чисельних методів математики.

Подання основного матеріалу дослідження. Закордонні дослідники з Національної академії наук США в своїй роботі [11], с. 11] про галузі інформатики (англ. Computer Science), як науки, зазначають, що в інформатиці досліджуються проблеми, що варіюють від властивостей електронних пристроїв до характеристик людського мислення, від окремих розроблених компонентів до глобально розподілених систем, від теоретичних досліджень алгоритмів до практичних проблем їх реалізації з точки зору обчислювального обладнання та програмного забезпечення.

Тобто інформатика, як зазначає М. І. Жалдак [12], с. 5], є комплексною дисципліною, до теоретичних основ якої відносять філософію, психологію, педагогіку, математику (зокрема обчислювальну математику), фізику, мікроелектроніку, нанотехнології, комп'ютерну інженерію, комп’ютерні мережі, телекомунікації, адміністрування комп'ютерних систем і мереж, програмування тощо.

Однією 3 важливих галузей інформатики $є$ багатопрофільна та міждисциплінарна галузь обчислювальна наука (англ. Computational Science) [13], сутність якої полягає в застосуванні обчислювальної математики стосовно розробки моделей для розуміння та розв'язання складних наукових проблем. Математичні методи, які необхідні для обчислювальної науки, вимагають перетворення рівнянь та функцій із неперервних у дискретні. Наприклад, комп'ютерне інтегрування функції здійснюється не шляхом застосування інтегрального числення, а, швидше, шляхом апроксимації площі під графіком функції як суми площ, отриманих в результаті дослідження функції в дискретних точках. Дослідженню таких чисельних методів присвячена обчислювальна математика.

Обчислювальна математика є теорією чисельних методів (методів обчислень або чисельним аналізом) розв'язування математично поставлених задач; побудови та дослідження відповідних обчислювальних алгоритмів, в яких використовують чисельне наближення для прикладних задач, заснованих на побудові математичних моделей; використання математики для вдосконалення комп’ютерних обчислень або використання комп'ютерів для самої математики.

Таким чином, чисельні методи (англ. Numerical Analysis) $є$ галуззю як математики, так i інформатики [14], тому $є$ так званою інформатично-математичною дисципліною інтегративної значущості 3 тісними міжпредметними зв’язками 3 іншими дисциплінами, що вивчаються студентами.

У зв’язку з цим цілком логічно, що навчання чисельних методів математики майбутніх вчителів інформатики передбачено в НПУ ім. М. П. Драгоманов на 3 курсі бакалаврату в складі нормативної частини науково-предметної підготовки вже після вивчення математичного аналізу, лінійної алгебри та аналітичної геометрії, математичної логіки та теорії алгоритмів, теорії програмування, теорії ймовірностей та математичної статистики.

В результаті вивчення чисельних методів студенти повинні вміти обгрунтувати вибір методу розв'язування математичної задачі, знати особливості його комп'ютерної реалізації, володіти алгоритмом методу, провести необхідні обчислення і аналіз отриманих результатів, а також мати навички практичного використання програмного забезпечення для розв'язування математичних задач [15], с. 6]. У курсі розглядаються такі основні поняття математики та інформатики, як модель, обчислювальний експеримент, обумовленість задачі, стійкість алгоритму, похибка обчислень та інші. Поєднання математичного апарату та засобів комп'ютерної математики, що використовуються в процесі навчання чисельних методів математики в свою чергу є підгрунтям для проведення наукових досліджень [4].

Згідно навчального плану підготовки вчителів інформатики на самостійну позааудиторну роботу студента в процесі навчання чисельних методів математики припадає майже 60\% часу, відведеного на навчання даної дисципліни, тобто на кожну годину аудиторної роботи припадає майже 1,5 години позааудиторної самостійної роботи студента. Аудиторний час розподіляється на лекційні та лабораторні заняття у співвідношенні 1:2. Окрім того має місце ще й аудиторна самостійна робота студентів, що виконується в межах часу, відведеного на загальний обсяг аудиторної роботи 
навчальних занять та регламентується за розкладом занять. Позааудиторна ж робота є менш регламентованою, тому і важко піддається управлінню. Залежно від своїх здібностей та зусиль студент встановлює режим і час виконання цієї роботи, яка контролюється викладачем 3 метою підвищення результативності навчання та визначення студентів, які відчувають труднощі i потребують методичної підтримки.

Позааудиторна самостійна робота студентів $є$ логічним продовженням аудиторних занять i включає в себе підготовку до навчальних занять, заліків, екзаменів та інших форм контролю, роботу 3 інформаційними ресурсами, розв'язування задач та виконання завдань лабораторних робіт, індивідуальних творчих завдань, дослідницьку діяльність. Ця робота виконується 3 використанням відповідного навчально-методичного забезпечення під опосередкованим управлінням викладача, який надає завдання, консультує, встановлює терміни виконання завдань [16], с. 53]. Разом 3 тим студенти свідомо повинні досягати поставленої у завданні мети.

Актуальною є думка М. І. Жалдака [12], с. 5; [17], с. 4] про те, що самостійна робота студентів є надзвичайно важливою складовою пізнавальної діяльності студентів, яку потрібно на основі спеціально розробленої сучасної комп'ютерно орієнтованої методичної системи навчання ретельно планувати, організовувати, контролювати, педагогічно виважено управляти нею 3 метою формування досить широкої бази до певної міри глибоких знань фундаментального характеру.

Тобто однією з важливих форм організації навчально-пізнавальної діяльності студентів стосовно курсу чисельних методів математики, яка має найбільшу питому вагу, є саме самостійна робота студентів. Для ефективної реалізації самостійної роботи студентів виникає потреба в систематичному педагогічному управлінні нею з педагогічно доцільним використанням сучасних засобів IКT.

Управління самостійною роботою студентів 3 боку викладача $\epsilon$ впорядкованою i цілеспрямованою діяльністю 3 планування, мотивації, організації, контролю та регулювання навчально-пізнавальної діяльності студентів [16], с. 56]. Комплексне навчально-методичне забезпечення дисципліни, однією з складових якого є засоби IКТ, виступає засобом навчання або управління самостійною роботою студентів.

Засоби IКТ, які використовуються для управління самостійною роботою студентів в процесі навчання чисельних методів математики, умовно можна поділити на засоби, з використанням яких можна лише управляти навчально-пізнавальною діяльністю студентів, і засоби, які окрім того виступають інструментом проведення навчальних та наукових досліджень, що дозволяє спростити виконання різноманітних обчислень, розширити коло задач для розв'язування, інтенсифікувати самостійну навчальну діяльність. В даному дослідженні звернемо увагу саме на другий тип таких засобів IКТ, тобто на програмні засоби комп'ютерної математики.

На етапі планування самостійної роботи студентів в процесі навчання чисельних методів математики діяльність викладача полягає в:

- розробці робочої програми навчальної дисципліни з зазначенням тематики та змісту самостійної роботи студентів, форм іiі звітності, запланованого часу та термінів іiі виконання, розподілу балів щодо оцінювання навчальних досягнень в результаті виконання завдань самостійної роботи;

- аналізі наявних методів та засобів навчання для управління самостійною роботою студентів, здійсненні добору елементів комп'ютерно орієнтованого інформаційно-освітнього середовища навчання, де буде розміщено весь комплекс завдань 3 позааудиторної самостійної роботи студентів, засобів контролю та самоконтролю та інших навчально-методичних матеріалів;

- проведенні діагностики рівня підготовки студентів для визначення ступеня готовності до сприймання нового матеріалу, кола питань, що потребують повторення під час самостійної роботи, визначення, за потреби, індивідуального плану навчання для кожного студента; добору задач різного рівня продуктивності самостійної діяльності (копіюючий, репродуктивний, частково-пошуковий, творчо-дослідницький);

- здійсненні добору систем комп'ютерної математики та його обгрунтуванні для навчання чисельних методів математики, враховуючи їх відповідність змісту навчальної дисципліни, рівню підготовленості студентів, запланованих методів та прийомів навчання.

Кількість програмних засобів комп'ютерної математики, що може бути використана в процесі навчання чисельних методів математики, в тому числі і управлінні самостійною роботою студентів, досить велика. Тому вивчення функціональних можливостей їх використання дає змогу викладачам обрати відповідні засоби ІКТ, враховуючи педагогічну доцільність стосовно розв'язування певного кола задач.

Розглянемо приклади використання безкоштовних програмних засобів комп'ютерної математики в процесі навчання чисельних методів математики для розв'язування задач апроксимації, зокрема інтерполювання, функцій. 
В якості основного засобу апроксимації майже в усіх галузях чисельних методів виступають поліноми. Вони використовуються в процесі розв'язування рівнянь та наближення функцій, обчислення інтегралів та похідних, розв'язування інтегральних та диференціальних рівнянь тощо. Цією популярністю поліноми зобов'язані своєю простою структурою, що дозволяє легко будувати ефективні наближення та потім використовувати їх. 3 цієї причини подання та обчислення многочленів $\epsilon$ основною темою чисельних методів математики. Розглянемо поліноміальну інтерполяцію, найпростіший $\mathrm{i}$, безумовно, найбільш розповсюджений метод для отримання поліноміальних наближень [18], с. 31].

Приклад. Використовуючи таблицю значень функції $y=f(x)=e^{x}+x$, обчислених в точках $x_{1}=-2, x_{2}=-1, x_{3}=0, x_{4}=1$, побудувати інтерполяційний поліном Лагранжа, що проходить через ці точки.

Розв'язування. Таблиця значень функції в заданих точках матиме наступний вигляд:

\begin{tabular}{|c|c|c|c|c|}
\hline$x_{i}$ & -2 & -1 & 0 & 1 \\
\hline$f\left(x_{i}\right)$ & -1.86466 & -0.63212 & 1 & 3.71828 \\
\hline
\end{tabular}

1. Використання програм навчального призначення Gran1, Gran-2D. Програмні засоби Gran1, Gran-2D розроблені українськими педагогами спеціально для комп'ютерної підтримки навчання шкільного курсу математики та призначені насамперед для розв'язування певних класів задач графічними методами і можуть бути віднесені до так званих програм-розв'язувачів [10], с. 4]. Однак студенти педагогічних університетів можуть їх використовувати і для розв'язування задач 3 чисельних методів математики, зокрема [5], с. 78]:

- відокремлення коренів нелінійних рівнянь графічним способом;

- розв'язування задачі лінійного програмування графічним способом для випадку цільової функції від двох змінних;

- опрацювання експериментальних даних;

- побудова емпіричних формул;

- побудова інтерполяційного многочлена для функції, що задана таблично.

Дані програмні засоби досить легкі для опанування. Водночас можна припустити, що студенти мали 3 ними справу в процесі навчання дисциплін математичного циклу на молодших курсах та в школі.

Для розв’язування подібних задач у програмно-методичному комплексі GRAN реалізований метод найменших квадратів. Дані необхідно вводити в табличному вигляді, тому в програмі Gran1 потрібно вказувати тип функціональної залежності «Таблична: $X_{i}, Y\left(X_{i}\right)$ » і звернутись до послуги «Об'єкт/Створити». В результаті чого з'явиться допоміжне вікно «Дані для апроксимування поліномом», в якому необхідно ввести дані, встановити степінь апроксимуючого полінома не вище 7 (для нашого прикладу степінь 3 , тобто на одиницю менше, ніж кількість вузлів інтерполювання), а також можна обрати колір та товщину ліній. Як в Gran1, так і в Gran-2D передбачена можливість введення даних для апроксимування поліномом з екрану за допомогою вказівника мишки, з файлу та 3 клавіатури.

В результаті у вікні «Список об’єктів» (рис. 1) буде відображено аналітичний вираз інтерполяційного поліному $y=g(x)=0.1144 x^{3}+0.5431 x^{2}+2.061 x+1, \quad$ яким найкраще наближається вище вказана таблично задана залежність у розумінні середнього квадратичного. Для графічного подання поліному слід скористатись послугою «Графік/Побудувати».

Для порівняння графічного подання інтерполяційного полінома та заданої функції $y=f(x)=e^{x}+x$ доцільно здійснити їх побудову (рис. 1 ), де пунктирною лінією синього кольору позначено графік функції $y=f(x)=e^{x}+x$, суцільною лінією червоного кольору - графік знайденого на відрізку $[-2 ; 1]$ інтерполяційного поліному

$$
y=g(x)=0.1143 x^{3}+0.54308 x^{2}+2.06077 x+1 .
$$

Обчислення інтерполяційного поліному Лагранжа студенти здійснюють за наступною формулою [15], c. 56]:

$$
\begin{gathered}
L_{n}(x)=\sum_{i=0}^{n} y_{i} \frac{\left(x-x_{0}\right)\left(x-x_{1}\right) \ldots\left(x-x_{i-1}\right)\left(x-x_{i+1}\right) \ldots\left(x-x_{n}\right)}{\left(x_{i}-x_{0}\right)\left(x_{i}-x_{1}\right) \ldots\left(x_{i}-x_{i-1}\right)\left(x_{i}-x_{i+1}\right) \ldots\left(x_{i}-x_{n}\right)}, \bar{i}=\overline{0, n} \\
L_{3}(x)=0.31078(x+1)(x-0)(x-1)-0.31606(x+2)(x-0)(x-1)-0.5(x+2)(x+1)(x-1) \\
+0.61971(x+2)(x-0)(x+1)=0.11443 x^{3}+0.54307 x^{2}+2.06076 x+1
\end{gathered}
$$




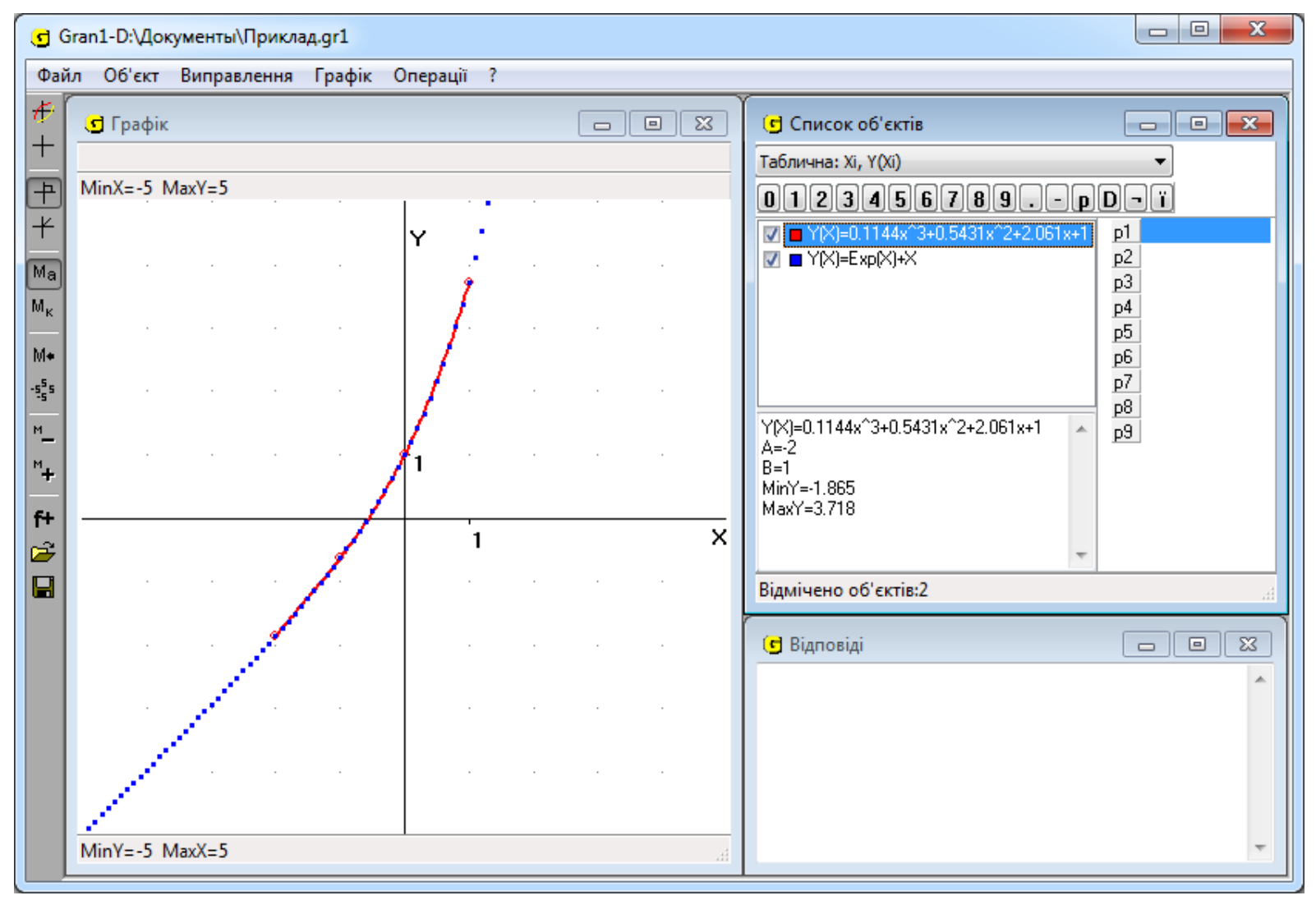

Рис. 1. Графічне подання інтерполяційного полінома та заданої функиії в Gran1

Тобто, щоб побудувати інтерполяційний многочлен Лагранжа, потрібно виконати значну обчислювальну роботу, в якій можна припуститись помилки. В такому разі використання програм Gran1, Gran-2D дозволяє студентам здійснити самоперевірку щодо правильності проведених розрахунків. Значення похибки інтерполяції, в разі необхідності, можна обраховувати за допомогою вбудованих калькуляторів, в яких в тому числі передбачена можливість обчислення похідної.

На відміну від Gran1, в Gran-2D коефіцієнти побудованого полінома округлюються до сотих, передбачена можливість вибору метода обчислення полінома (степеня не вище 10 за методом найменших квадратів або полінома Лагранжа) та здійснення на графіку зміни вузлів інтерполювання 3 динамічним перерахунком полінома.

Переважна більшість самостійної роботи студента здійснюється за межами аудиторії, тому зрозумілою $є$ потреба як у студентів, так і у викладачів в таких програмних засобах комп'ютерної математики, використання яких було б можливим незалежно від платформи або пристрою, що $\epsilon$ в наявності. Найпростішим шляхом забезпечення такої потреби $є$ використання web-орієнтованих систем комп'ютерної математики. Тому в зв'язку з сучасними тенденціями розвитку технологій навчання з трансформацією в комп'ютерно орієнтоване, змішане, дистанційне навчання відбувається i логічна переорієнтація розробників традиційних десктопних програмних продуктів до впровадження ïx web-інтерфейсу i забезпечення таким чином зазначеної потреби в кросплатформеності, і разом з тим, в разі безкоштовності доступу до них, економічної доцільності до використання в закладах вищої освіти.

До таких web-орієнтованих засобів розв'язуваня математичних задач можна віднести систему Wolfram|Alpha від компанії Wolfram Research, яка являє собою обчислювальну машину знань (англ. Computational Knowledge Engine) генерації відповідей на запити користувачів з використанням вбудованих в неї методів і алгоритмів та бази даних [19].

2. Використання обчислювальної системи знань Wolfram|Alpha. Система Wolfram|Alpha використовується як інтернет-сервіс, обчислювальне ядро якої базується на системі комп'ютерної математики Mathematica від того ж виробника. Для виконання всіх операцій використовується мова програмування Wolfram Language 3 елементами штучного інтелекту, тому користувачам не обов'язково дотримуватися строгого синтаксису запитів, які подаються англійською мовою. Для уникнення мовного бар'єру можна скористатись інтегрованим в браузер автоматичним перекладачем або відповідним програмним розширенням браузера. Для введення запитів за аналогією з класичними пошуковими системами призначено рядок запитів, але результатом виконання запиту користувача $\epsilon$ згенерована за програмою на основі ііі бази знань відповідь, а не список посилань на веб-сторінки. 


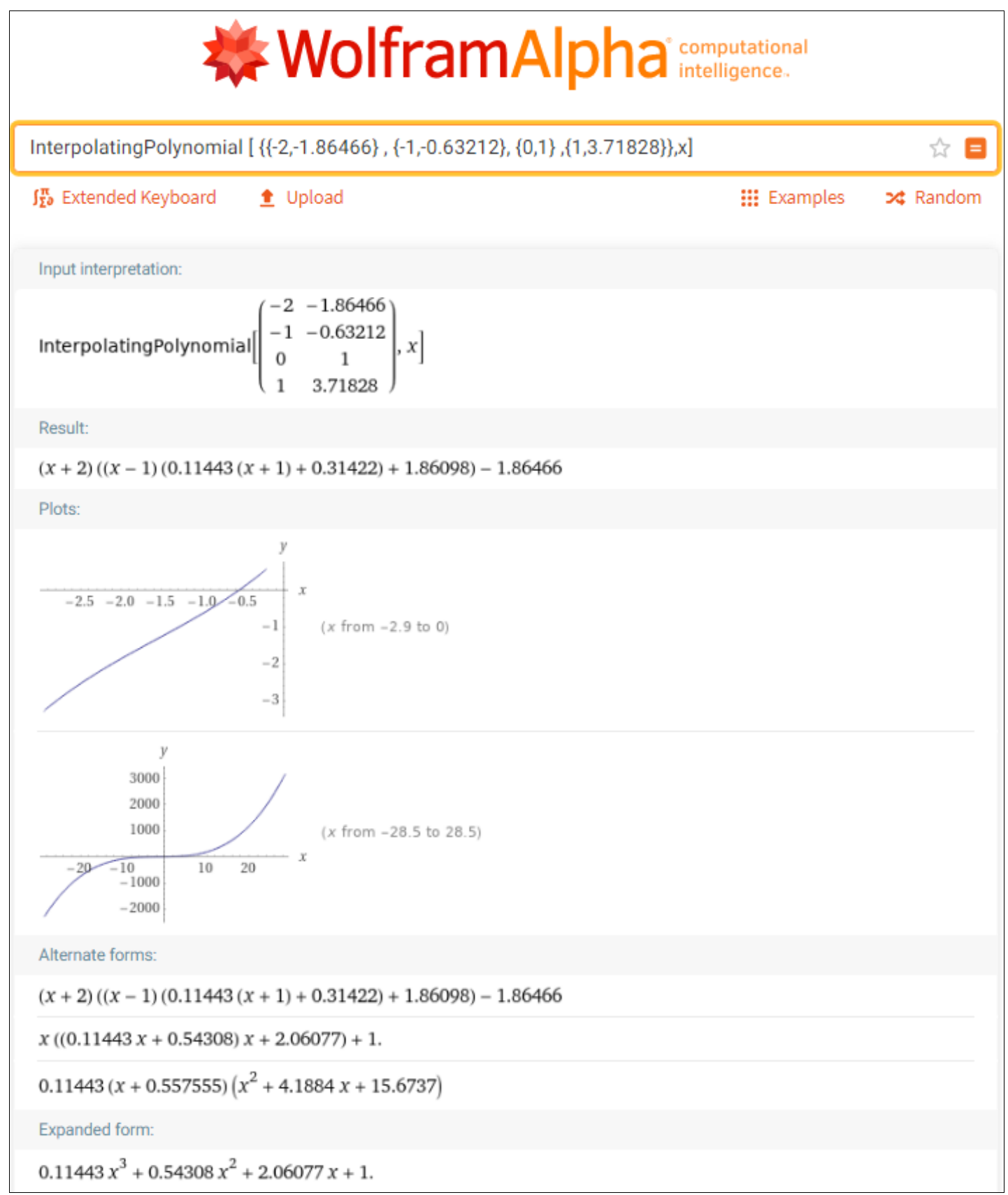

Puc. 2. Результати виконання запиту в Wolfram|Alpha

До системи входять сотні наборів даних з багатьох дисциплін: історичних, фінансових, економічних, географічних, метеорологічних, лексичних та інших. 3 математичної точки зору вона являє собою систему комп'ютерної математики, з використанням якої можна здійснювати символьні та числові обчислення, візуалізацію.

B Wolfram|Alpha можна ознайомитись 3 прикладами запитів та їх результатами стосовно розв'язування задач з використанням наступних чисельних методів:

- чисельні методи розв'язування рівнянь: метод Ньютона (Newton's method), метод хорд (secant method), метод половинного ділення (bisection method);

- методи чисельного інтегрування функцій: метод лівих прямокутників (left endpoint method), метод правих прямокутників (right endpoint method), метод середніх прямокутників (midpoint method), метод трапецій (trapezoidal method), метод Сімпсона (метод парабол) (Simpson's method);

- методи чисельного диференціювання функцій: метод Рунге-Кутта (Runge-Kutta method), прямий та зворотний метод Ейлера (Euler method, backward Euler), метод середньої точки (with midpoint method,тобто удосконалений метод Ейлера), метод Хойна (Heun method).

Такі приклади можна отримати, якщо в системі виконати запит, наприклад, за словосполученням «numeric analisis» (чисельний аналіз) [20].

Разом 3 тим, у мові програмування Wolfram Language передбачено функції [21], які можна використовувати в Wolfram|Alpha для розв'язування наступних задач на візуалізацію даних та апроксимацію кривих: 
- візуалізація даних у вигляді точкової діаграми (функція ListPlot), стовпчикової діаграми (функція BarChart), у вигляді лінії, що з’єднує задані точки (функція ListLinePlote);

- проста експоненціальна апроксимація кривих (функція FindFit);

- розв’язування задачі найменших квадратів в матричній формі (функція LeastSquares);

- інтерполяція функцій (функції Interpolation, ListInterpolation, FunctionInterpolation, InterpolatingFunction);

- побудова інтерполяційних поліномів (функція InterpolatingPolynomial);

- інтерполювання функцій за допомогою сплайнів, не лише кубічних, але і сплайни будь-якого ступеня - для кривих, поверхонь будь-якої розмірності (BezierFunction, BSplineFunction - функції для побудови кривих Безьє за вказаними даними; BernsteinBasis, BSplineBasis - функції для відшукання базисних поліномів Берштейна);

- відшукання лінійної регресії за методом найменших квадратів (функція Fit).

Для розв'язування задачі на відшукання поліному Лагранжа 3 використанням Wolfram|Alpha потрібно за адресою http://www.wolframalpha.com в полі введення запиту скористатись функцією InterpolatingPolynomial[ $\left.\left\{\left\{x_{1}, f_{1}\right\},\left\{x_{2}, f_{2}\right\}, \ldots\right\}, x\right]$ мови програмування Wolfram Language. Вона призначена для побудови інтерполюючого полінома для значень функції $f_{i}$, що відповідають значенням $x_{i}$. Стосовно наведеного прикладу запит користувача матиме такий вигляд:

InterpolatingPolynomial $[\{\{-2,-1.86466\},\{-1,-0.63212\},\{0,1\},\{1,3.71828\}\}, x]$

В результаті запиту на поточній сторінці будуть згенеровані результати обчислень: аналітичний вигляд інтерполяційного полінома в різних формах, зокрема $\mathrm{i}$ в наступній: $0.1144 x^{3}+0.54308 x^{2}+2.06077 x+1$, а також побудовано його графіки (рис. 2).

Для того, щоб скористатись ширшими функціональними можливостями використання даної системи, наприклад, зберегти результат запиту у форматі PDF, збільшити масштаб побудови або змінити інші налаштування візуалізації, переглянути покрокові розв'язки задачі, збільшити час розрахунку, здійснити введення даних з файлу, потрібно зареєструватись та придбати підписку 3 тарифним планом Рro. Для безкоштовної версії зареєстрованим користувачам надається можливість лише перегляду історії власних запитів та налаштування уподобань.

Для підсилення мотивації щодо розв' язування даного класу задач можна скористатись ще однією розробкою виробника Wolfram Research - проектом Wolfram Demonstration Project. Станом на сьогодні він містить більше, ніж 12000 програм-демонстрацій, що візуально доносять відомості 3 різних галузей знань. Наприклад, проект містить демонстрацію інтерполяційного полінома степеня 5, що проходить через 6 вузлів інтерполювання, положення яких можна змінювати за допомогою вказівника мишки. Або демонстрацію [22] щодо порівняння кубічної сплайн-інтерполяції та інтерполяційного полінома.

2. Використання хмаро оріснтованої системи комп'ютерної математики SageMathCloud. SageMathCloud - хмаро орієнтований варіант системи комп'ютерної математики SageMath, яка $\epsilon$ вільно поширюваною альтернативою пропрієтарному математичному програмному забезпеченню (Magma, Maple, Mathematica, MATLAB) 3 відкритим програмним кодом для використання в дослідженнях і навчанні. SageMath базується на багатьох існуючих пакетах з відкритим кодом: NumPy, SciPy, matplotlib, Sympy, Maxima, GAP, FLINT, R та багатьох інших [23], [24].

Спектр функціональних можливостей використання SageMath охоплює багато розділів математики та інформатики [6], [7], [8] від теорії чисел і алгебри до геометрії та чисельних обчислень, комбінаторику, теорію графів. SageMath найчастіше використовується в університетських дослідженнях та навчанні. На головній сторінці SageMath [23] перераховано більше 400 наукових статей, книг і тез, в дослідженнях яких було використано дану програму.

Використання SageMathCloud, як засобу навчання математичних та інформатичних дисциплін, дозволяє викладачеві в хмаро орієнтованому середовищі налаштовувати спільну роботу студентів, переглядати історію змін файлів, здійснювати автоматичне та ручне оцінювання результатів діяльності студентів, взаємодіяти зі студентами через панель чату, писати та запускати програмний код на виконання, обираючи для цього необхідне обчислювальне ядро: Gap, Julia, Python, R, Prolog, Octave, SageMath, Scala. Для використання SageMathCloud, як i Wolfram|Alpha, передбачено безкоштовні та платні тарифні плани, відмінність яких полягає в швидкості виконуваних обчислень.

Робота з SageMathCloud відбувається в проекті - особистому робочому просторі користувача, в якому зберігаються ресурси різних типів, основні з яких:

- Sage Worksheets - файли (*.sagews), які називають робочими аркушами та складаються 3 прямокутних комірок програмного коду. Для кожної комірки передбачено область введення та виведення. Введення за замовчуванням математичне у синтаксисі SageMath, або може бути в 
інших форматах, зокрема, Markdown, HTML, Python, R та інші. Робочі аркуші були створені для роботи з SageMath на платформі SageMathCloud.

- Jupyter Notebooks - файли (*.ipynb), які називають блокнотами та містять синхронізований запис сеансу із обчислювальним ядром (Python, Gap, Julia, R, Prolog, Octave, SageMath, Scala). Як i робочі аркуші SageWorksheets, вони складаються 3 комірок програмного коду, в яких може зберігатись один або кілька рядків коду або відформатований текст. Після запуску на виконання програмного коду в комірках через активний сеанс ядра здійснюється виведення результатів обчислення.

- LaTeX document - технічний документ (*.tex) професійної якості з складними математичними формулами, в якому використовується мова розмітки та процесор для набору документів LaTeX.

- Manage a Course - послуга, за допомогою якої викладач має можливість створити навчальний курс, зараховувати студентів до нього, здійснювати автоматичне створення проектів для студентів, призначати їм завдання, оцінювати результати їх роботи. В результаті вибору даної послуги створюється файл управління курсом (*.course), за допомогою якого здійснюється контроль різних налаштувань курсу.

В багато системах комп'ютерної алгебри, наприклад, Maple, Mathematica i MATLAB, передбачено реалізацію нової мови програмування, специфічної для цієї системи. Навпаки, в SageMath використовується популярна і широко розповсюджена мова програмуванням високого рівня Python. Python вважається простою та легкою для навчання, в якій можна визначати нові методи та типи даних для навчання математики. Однією 3 переваг SageMath в науковому програмуванні $є$ безкоштовна доступність вихідного коду і відкритість розробки. Алгоритми більшості комерційних програм не є загальнодоступними, що унеможливлює перегляд і перевірку функціональності коду. Тому використання вбудованих функцій цих програм може бути неадекватним в деяких математичних дослідженнях, заснованих на результатах, отриманих за допомогою цих алгоритмів [6].

Для розв'язування задачі на відшукання поліному Лагранжа в SageMathCloud можна скористатись нижче наведеними підходами.

I підхід: використання команд системи комп'ютерної математики SageMath. В новому робочому аркуші «Sage Worksheet», який за замовчуванням налаштований на роботу 3 командами SageMath, потрібно ввести такий програмний код та запустити його на виконання:

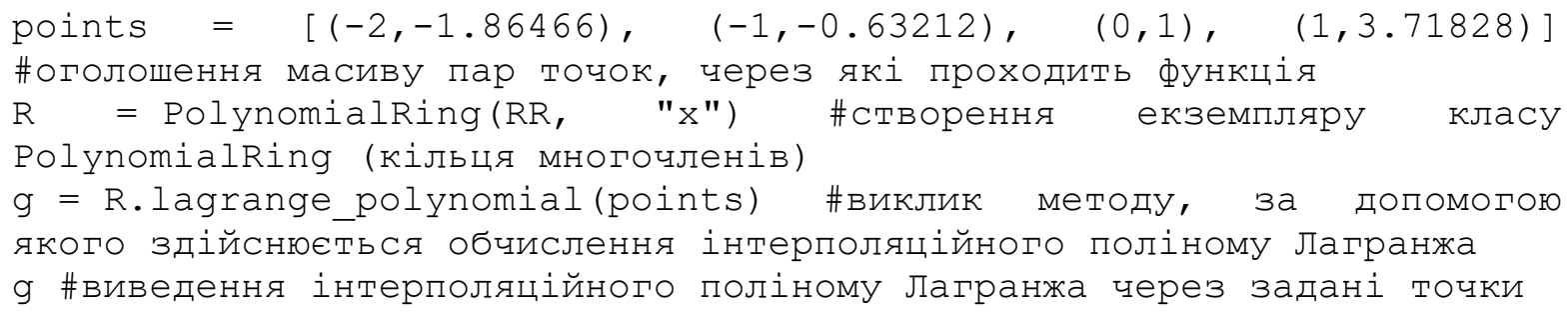

Архітектура SageMath для поліномів є складною та поєднує різні бібліотеки мов програмування $\mathrm{C} / \mathrm{C}++$ для поліномів над кільцями. Більшість класів поліноміальних елементів реалізовані як типи розширень скомпільованої на основі Python мови програмування Cython, а не як чисті класи Python [25]. У багатьох ситуаціях інтерпретатор Руthon досить швидкий для звичайних обчислень. Однак іноді для чисельних обчислень потрібна значна швидкість типів мови програмування С для змінних і атрибутів класів. Тому в SageMath використовується Cython для написання швидких модулів розширення Python і взаємодії Python з бібліотеками C [6]. Для обчислення інтерполяційного поліному ми скористались методом lagrange_polynomial класу кільця многочленів PolynomialRing. За замовчуванням в даному методі використовується метод скінчених різниць [25].

Для побудови графіка інтерполяційного полінома скористаємось функцією plot, призначеною для побудови графіків функціональних залежностей, заданих аналітично в декартовій системі координат. Для порівняння графіків заданої функції та знайденого поліному побудуємо їх в одній системі координат на відрізку [-2,1] (рис. 3), де суцільною лінією синього кольору позначимо графік функції $y=f(x)=e^{x}+x$, пунктирною лінією червоного кольору - графік знайденого інтерполяційного поліному $y=g(x)=0.1143 x^{3}+0.54308 x^{2}+2.06077 x+1$. Програмний код виглядатиме наступним чином:

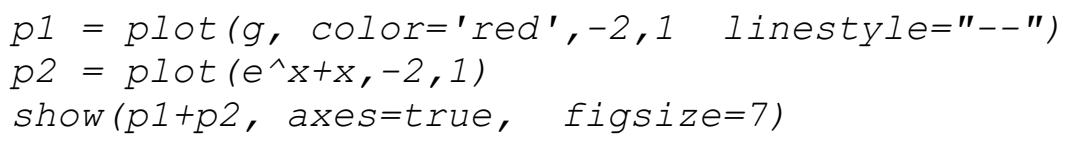




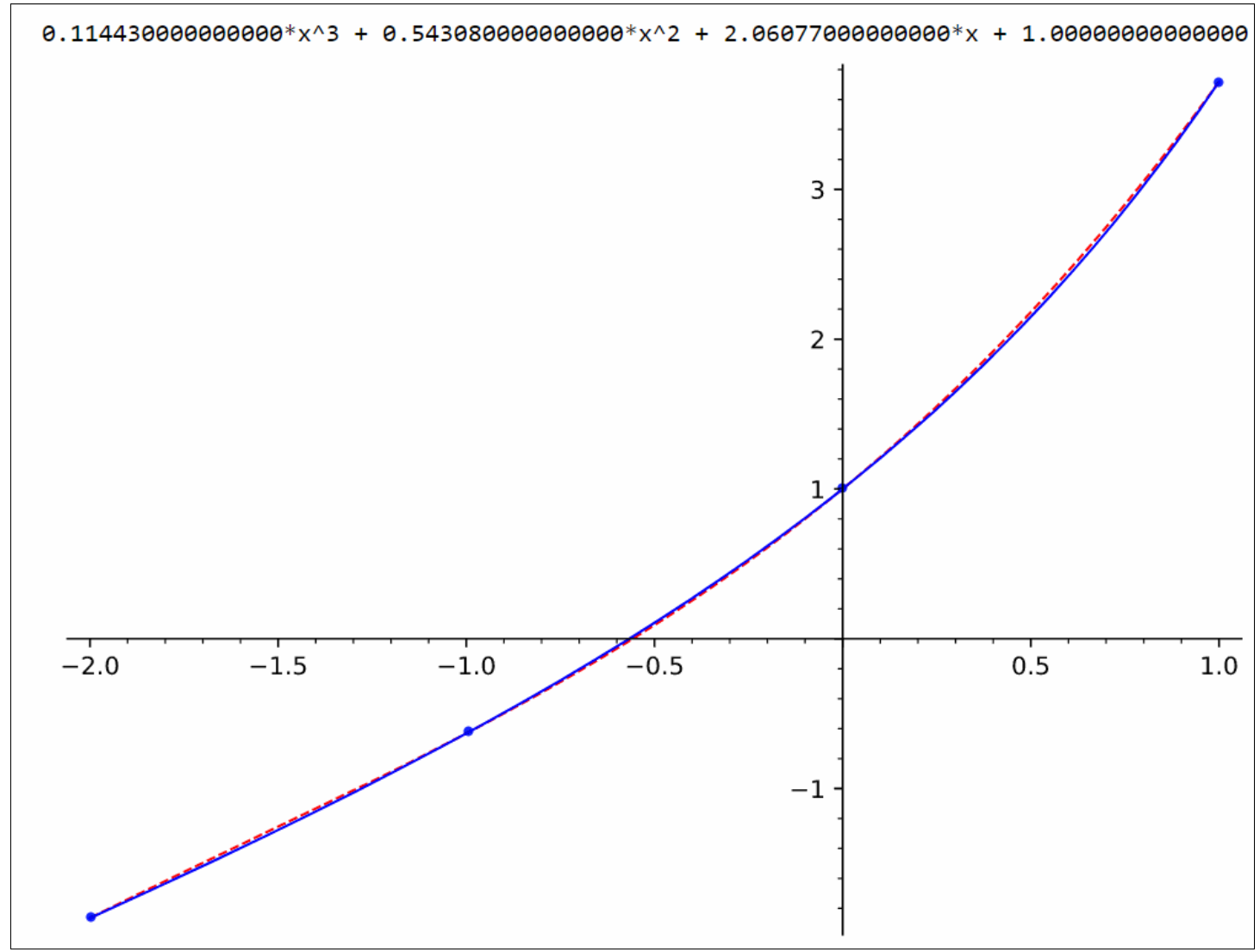

Рис. 3. Результат розв'язування задачі в SageMathCloud з використанням математичного синтаксису SageMath

II nidxid: використання мови програмування Python. В новому блокноті «Jupyter Notebook» потрібно ввести наступний програмний код та запустити його на виконання:

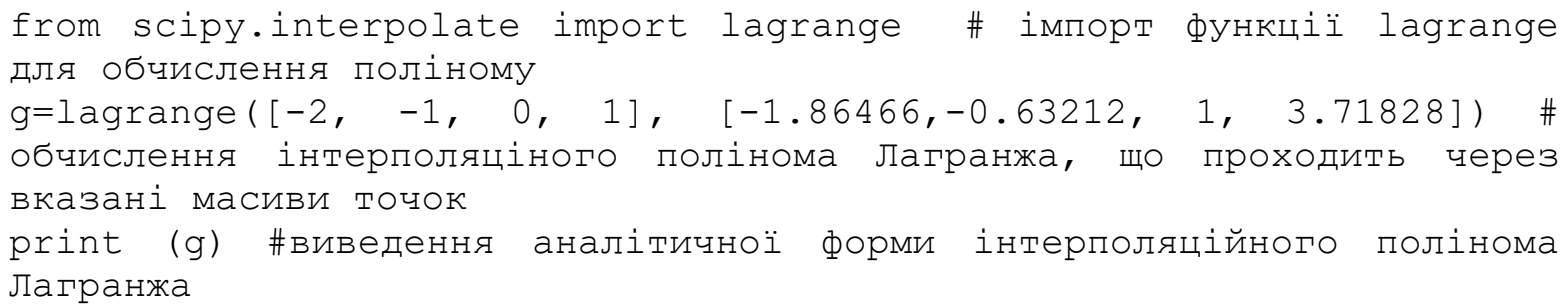

B SageMath використовується кілька програмних бібліотек, які можна використовувати під час застосування чисельних методів математики. Найбільш суттєві з них NumPy та SciPy, які є модулями розширення мови програмування Pуthon та призначені для виконання наукових та інженерних розрахунків. Щоб використовувати ці пакети в SageMath, вони повинні бути імпортованими в сеанси SageMath за допомогою оператора імпорту import. Для обчислення поліному Лагранжа ми скористались функцією lagrange пакету Interpolation бібліотеки SciРу. Пакет Interpolation [26] використовується для інтерполяції та містить сплайнові функції та класи.

Для побудови інтерполяційного поліному скористаємось пакетом Pyplot бібліотеки Matplotlib, яка призначена для візуалізації двомірних графіків, та функцією arange бібліотеки NumРу, яка призначена для генерації одновимірного масиву з рівномірно рознесеними значеннями всередині заданого інтервалу. Програмний код виглядатиме наступним чином (результат виконання на рис. 4):

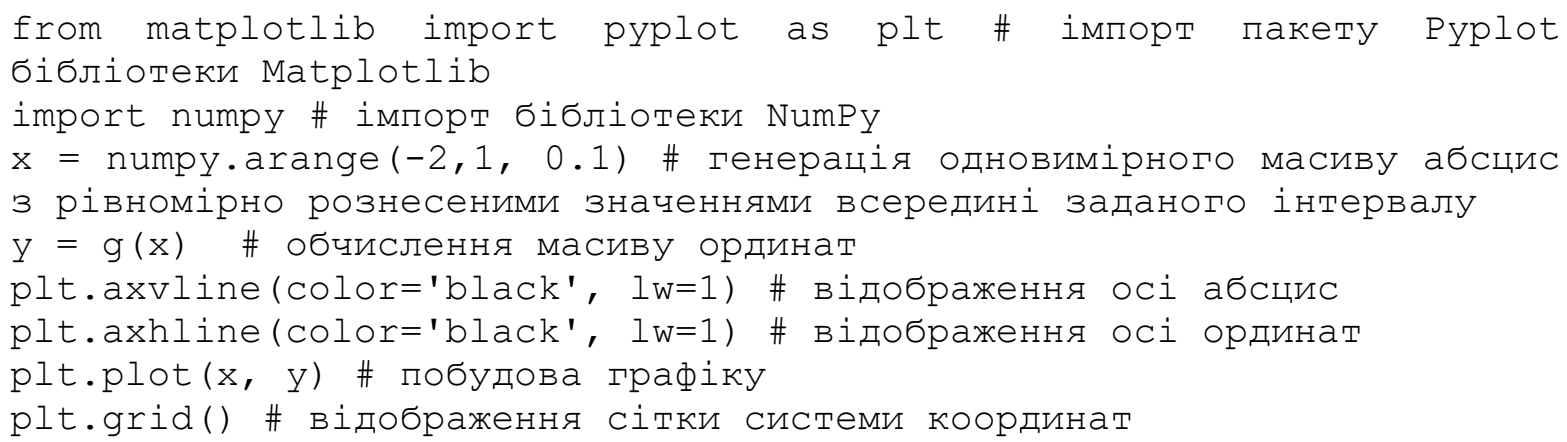




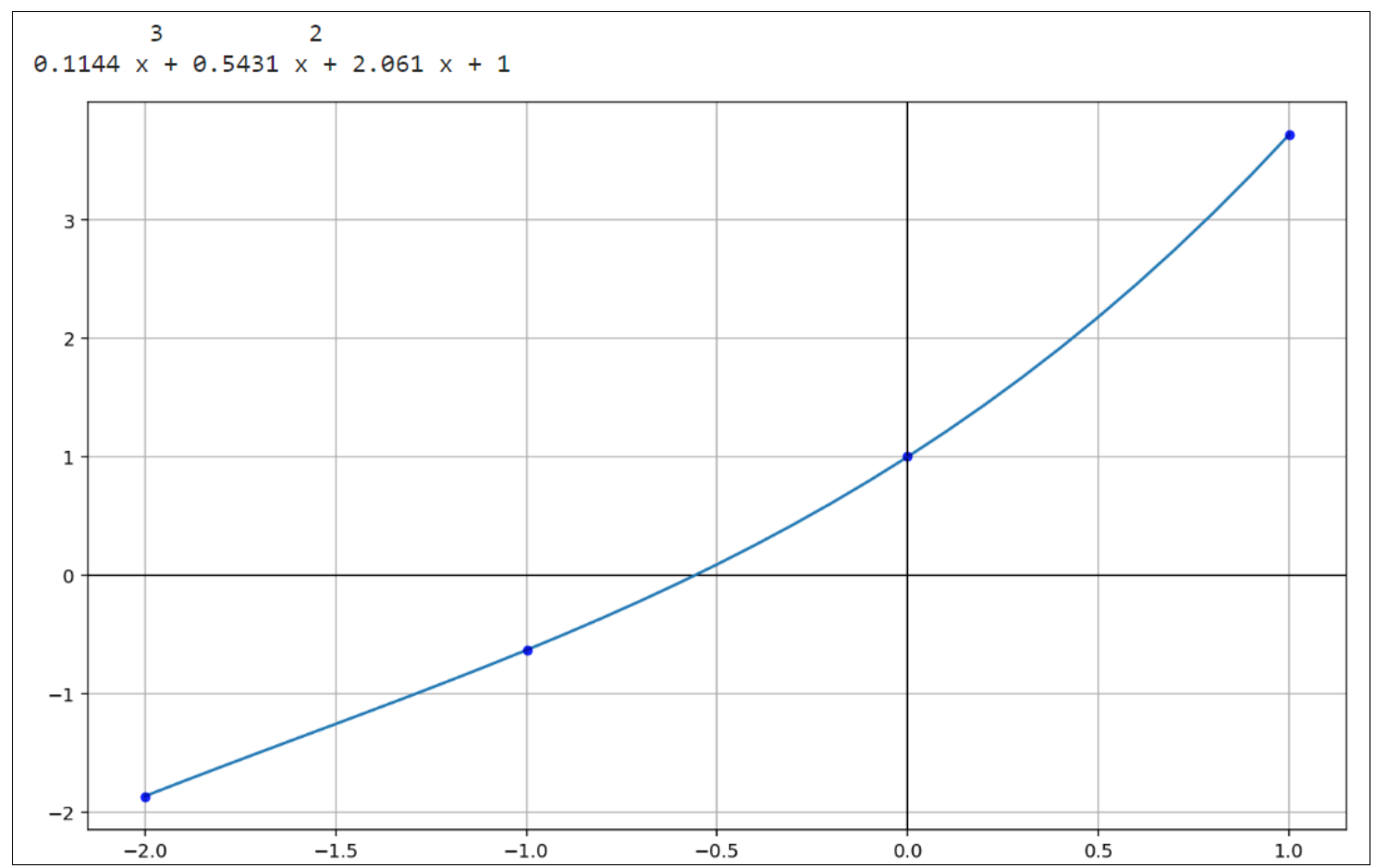

Pис. 4. Результат розв'язування задачі в SageMathCloud з використанням Python

III підхід: використання власного алгоритму інтерполювання за інтерполяційною формулою Лагранжа з застосуванням засобів мови програмування. В якості мови програмування оберемо Python. Використання третього способу дозволяє саме закріпити та перевірити знання математичного алгоритму відшукання поліному Лагранжа та підсилити міжпредметні зв'язки програмування та математичного аналізу. Програмний код такої реалізації в блокноті «Jupyter Notebook» SageMathCloud може виглядати наступним чином:

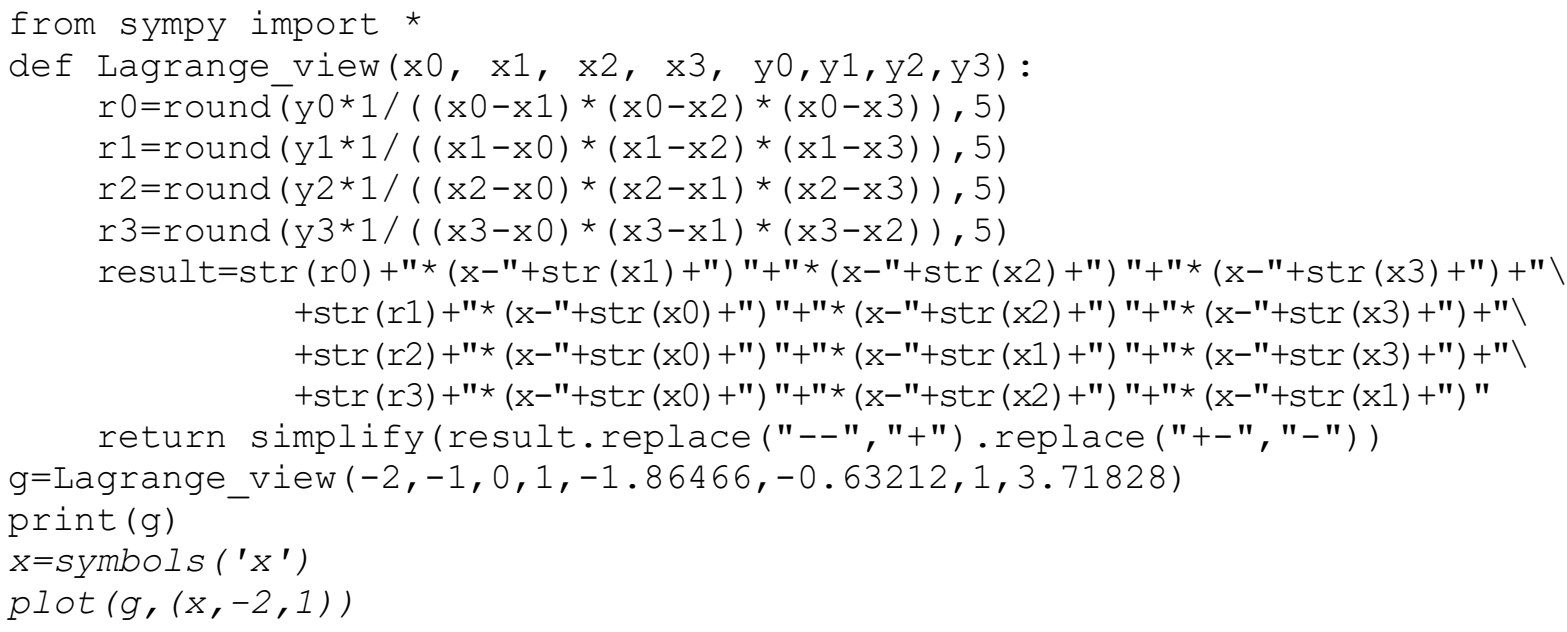

Для спрощення запису поліному Лагранжа ми скористались ще однією бібліотекою Python, a саме SymPy, яка призначена для символьної математики та містить функції для виконання різного роду спрощень, зокрема функцію simplify.

Програмний код мови Python можна також використовувати не лише в блокноті «Jupyter Notebook», а й в робочому аркуші «Sage Worksheet», перейшовши для цього до відповідного режиму за допомогою послуги «Modes» («Режими») панелі інструментів для команд SageMath або команди \%python.

Варто зазначити, що створену функцію для відшукання полінома Лагранжа можна використати для розв'язування складніших задач з чисельних методів, як одного з етапів в процесі чисельного інтегрування або диференціювання.

Студенів, які добре опанували чисельними методами та володіють навичками програмування, можна залучати до серйозних наукових досліджень або виконання індивідуальних проектів, наприклад, зі створення калькулятора поліномів Лагранжа тощо. Зокрема, як показує досвід, однією 3 ефективних форм самостійної роботи студентів може бути групова робота над завданнями, під час якої підвищується рівень самоконтролю, мотивації, комунікації, пізнавальна та творчо-дослідницька активність. 


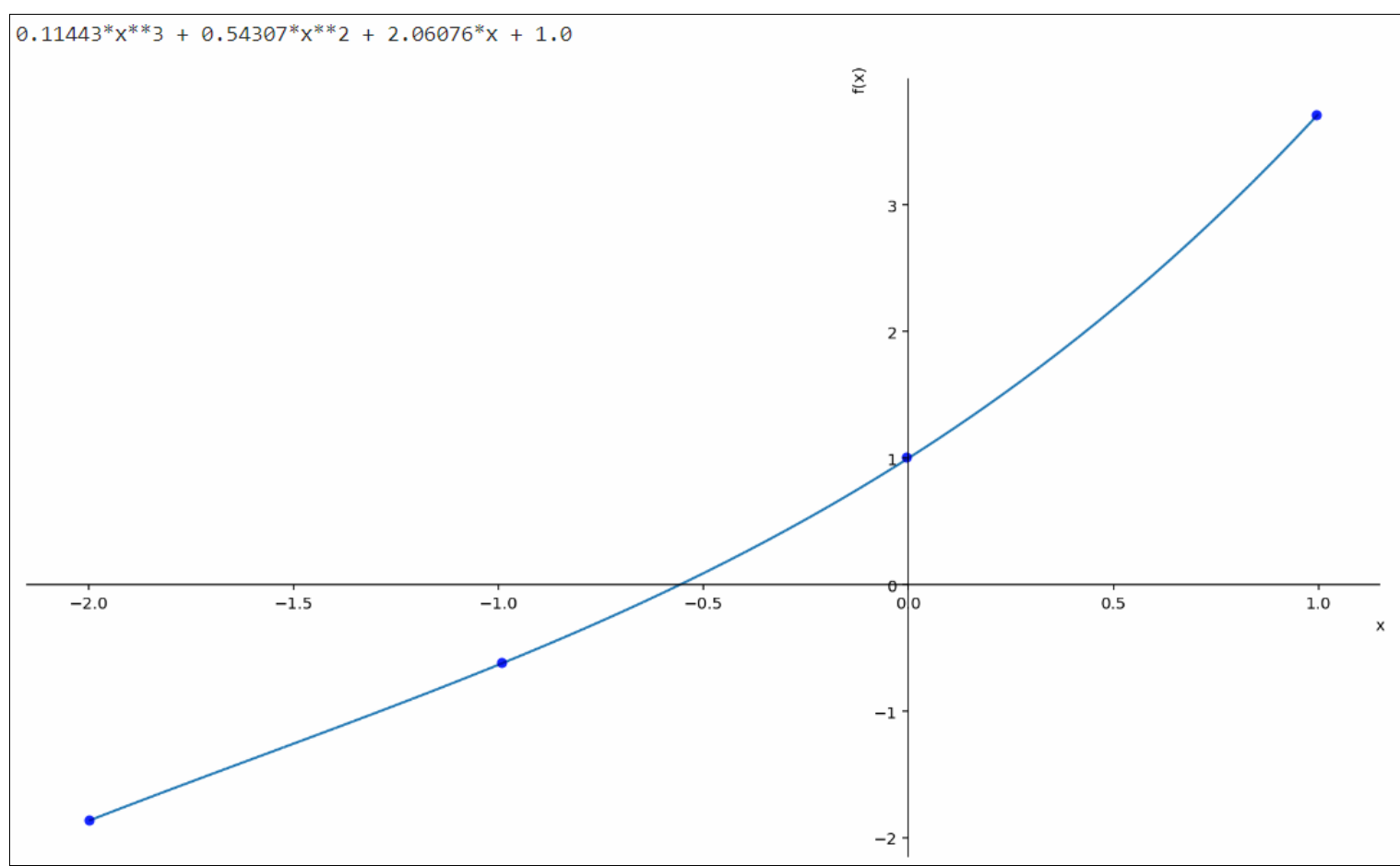

Рис. 5. Результат розв'язування задачі в SageMathCloud з використанням алгоритму інтерполювання описаного мовою Pуthon

Висновки. Програмні засоби Gran1 та Gran-2D відрізняє серед запропонованих засобів комп'ютерної математики україномовний інтерфейс, легкість для опанування, відсутність webінтерфейсу, наявність потужної україномовної навчально-методичної підтримки, як від розробників даних засобів, так і від широкого кола педагогів. Їх використання дозволяє швидко будувати інтерполяційні поліноми та використовувати для розв'язування різних задач 3 чисельних методів математики, що не вимагає глибоких знань для початківця.

Обчислювальна система знань Wolfram|Alpha характеризується кросплатформеністю, англомовним інтерфейсом, опрацюванням запитів природною англійською мовою, виведенням в результаті обчислень різних інтерпретацій розв'язків, зокрема аналітичного подання полінома в різних формах та його графіків, опису властивостей математичних об'єктів, побудовою їх графіків та інших візуалізацій, а також схожих за темою прикладів. Тобто виведенням лише за одним запитом великого масиву даних 3 вказаної предметної галузі. Однак для розв'язування математичних прикладів можуть знадобитись вміння формулювати запити 3 використанням синтаксису мови програмування Wolfram Language, для підтримки використання якого наявні сайти з готовими прикладами. Для уникнення мовного бар'єру, можна скористатись інтегрованим в браузер автоматичним перекладачем. Wolfram|Alpha доцільно використовувати в якості додаткового освітнього ресурсу, через застосування якого підтримуються можливості обчислення та інтерпретації нетривіальних запитів.

Розв'язування задач у середовищі SageMathCloud потребує використання команд мов програмування, а також команд систем комп'ютерної математики, що на перший погляд вимагає наявності у користувача високого рівня знань, необхідних для початку роботи з програмою. Однак, 3 одного боку можна використовувати сайти підтримки відповідних засобів, а 3 іншого - вивчення чисельних методів математики відбувається в другому семестрі третього курсу після значної кількості дисциплін інформатичного та математичного циклів, в процесі яких студенти опановують в тій чи іншій мірі системи комп’ютерної математики та мови програмування.

SageMathCloud доцільно використовувати для розв'язування більш складних задач з чисельних методів, в яких відшукання полінома Лагранжа є лише одним із етапів розв'язування задачі, як наприклад в процесі чисельного інтегрування або диференціювання. Таким чином, студенти можуть створювати свої власні програми для розв'язування складних прикладних задач. Водночас 3 використанням команд мов документування - якісні навчально-математичні або науково-математичні тексти як статичного, так і динамічного змісту, що дозволяє надати навчальній діяльності творчого та дослідницького характеру, позбавивши рутинних розрахунків. Однак, використання безкоштовного доступу до SageMathCloud може уповільнювати швидкість розрахунків в 10 разів.

Серед переваг використання SageMathCloud варто відзначити наявність додаткових можливостей щодо управління самостійною роботою студентів: можливість створювати навчальні курси, 
зараховувати студентів до них, здійснювати автоматичне створення проектів для студентів, призначати їм завдання, оцінювати результати їх роботи, організовувати спільну роботу студентів, взаємодіяти через панель чату, створювати навчальні матеріали динамічного змісту.

Таким чином, для управління самостійною роботою майбутніх вчителів в процесі розв'язування задач 3 чисельних методів математики доцільно використовувати: на окремих етапах в якості допоміжного засобу, зокрема для самоконтролю або позбавлення рутинних розрахунків, програмирозв'язувачі Gran 1, Gran-2D; в якості додаткового освітнього ресурсу з можливостями застосування в процесі обчислень, - систему знань Wolfram|Alpha; в якості комплексного засобу для розв'язування складних прикладних задач творчо-дослідницького характеру, зокрема, в процесі підготовки курсових та бакалаврських робіт, а також як інтегрований засіб щодо управління самостійною роботою студентів - хмаро орієнтовану систему комп'ютерної математики SageMathCloud.

Відтак, можна впевнено стверджувати, що запропоновані програмні засоби, окрім того що $\epsilon$ потужною альтернативою комерційним системам комп'ютерної математики, застосування переважної більшості з них ще й забезпечує сучасну потребу в кросплатформеності, а також можуть використовуватись на різних етапах управління самостійною роботою студентів: планування (наприклад, для розміщення навчально-математичних матеріалів), мотивація (наприклад, використання демонстраційних динамічних прикладів), організація (наприклад, організація спільної роботи студентів), контроль (наприклад, оцінювання, самоконтроль).

Окрім того управління самостійною роботою майбутніх вчителів 3 використанням різних програмних засобів комп'ютерної математики в процесі навчання чисельних методів математики сприяє підвищенню рівня ІКТ-обізнанності студентів, розвитку їх творчо-дослідницьких умінь, глибшому розумінню міжпредметних зв'язків, умінню добирати такі засоби в залежності від поставлених задач, а також методів та алгоритмів, що покладені в основу виконання команд програмних засобів.

Перспективи подальших досліджень полягають в аналізі дидактичних можливостей використання інших програмних засобів комп'ютерної математики, наприклад, Scilab, який оснащений схожою 3 комерційною системою комп'ютерної математики MATLAB мовою програмування, або MathPiper, в який вбудовано систему підтримки автоматичного оцінювання студентських програм та прикладних математичних задач, оскільки розроблений спеціально для використання в навчанні.

\section{Список використаних джерел}

[1] Toffler A. Future Shock. New York: Bantam Books, 1971. 430 p.

[2] Knight P. Independent Study, independent studies and 'core skills' in higher education. The management of independent learning / eds. J. Tait, P. Knight. London: Kogan Page in association with SEDA, 1996. P.29-37.

[3] Bilousova L., Kolgatin O., Kolgatina L. Computer Simulation as a Method of Learning Research in Computational Mathematics. CEUR Workshop Proceedings. 2019. № 2393, P. 880-894.

[4] Рамський Ю. С., Рафальська М. В. Формування компетентностей майбутніх вчителів інформатики та математики у галузі моделювання. Науковий часопис НПУ імені М.П. Драгоманова. Серія №2. Комп’ютерно-орієнтовані системи навчання. 2012. №12 (19). C. 117-127.

[5] Рафальська М. В. Формування ІКТ-компетентностей майбутніх вчителів математики та інформатики у процесі навчання методів обчислень. Науковий часопис НПУ імені М. П. Драгоманова. Серія 2 : Комп'ютерно-орієнтовані системи навчання. 2017. № 19. C. 78-83.

[6] Ruotsalainen L., Vuorinen M. Numerical methods with Sage. Tbilisi Mathematical Journal. 2012. Vol. 5, № 2, P. 101-119. doi:10.32513/tbilisi/1528768905.

[7] Попель М. В. Організація навчання математичних дисциплін у SageMathCloud: навчальний посібник. Теорія та методика навчання математики, фізики, інформатики. Кривий Ріг, 2016. Том 14. № 1(38). С. 3-110.

[8] Шокалюк С. В., Маркова О. М., Семеріков С. О. SageMathCloud як засіб хмарних технологій комп'ютерно-орієнтованого навчання математичних та інформатичних дисциплін. Моделювання в освіті: Стан. Проблеми. Перспективи : монографія / за заг. ред. В. М. Соловйова. Черкаси, 2017. C. $130-142$.

[9] Nečesal P., Pospíšil J. Experience with teaching mathematics for engineers with the aid of Wolfram Alpha. Proceedings of the World Congress on Engineering and Computer Science: WCECS 2012, October 24-26, 2012. San Francisco, USA. vol. 1, P. 271-274. 
[10] Жалдак М. І., Горошко Ю. В., Вінниченко С. Ф. Математика 3 комп’ютером: посібник для вчителів. Київ, 2015. 315 с.

[11] National Research Council. Computer Science: Reflections on the Field, Reflections from the Field. Washington, DC: The National Academies Press, 2004. 216 p. doi: 10.17226/11106.

[12] Жалдак М. I. Проблеми фундаменталізації змісту навчання інформатичних дисциплін в педагогічних університетах. Науковий часопис НПУ імені М.П. Драгоманова. Серія №2: Комп'ютерно-орієнтовані системи навчання. 2015. № 17. С. 3-15.

[13] Tucker A., Belford G. G. Computer science. Encyclopedia Britannica. URL: https://www.britannica.com/science/computer-science (viewed on January 12, 2020).

[14] Atkinson K. Numerical analysis. Encyclopedia Britannica. URL: https://www.britannica.com/science/numerical-analysis (viewed on January 12, 2020).

[15] Ляшенко Б. М., Кривонос О. М., Вакалюк Т.А. Методи обчислень: навч.-метод. посіб. Житомир, 2014. $228 \mathrm{c}$.

[16] Вакуленко I. В.Управління самостійною роботою студентів з використанням інформаційнокомунікаційних технологій. Науковий часопис НПУ імені М.П. Драгоманова. Серія №2: Комп'ютерно-орієнтовані системи навчання. 2016. № 18 (25). С. 50-64.

[17] Жалдак М. І. Інформатизація навчального процесу має сприяти поглибленню і розширенню бази знань - основи творчої діяльності майбутнього фахівця. Науковий часопис НПУ імені М.П. Драгоманова. Серія №2: Комп'ютерно-орієнтовані системи навчання. 2016. № 18. С.3-6.

[18] Conte S. D., de Boor C. Elementary Numerical Analysis: An Algorithmic Approach, McGraw-Hill, New York, 1980. 432 p.

[19] About Wolfram|Alpha. Making the world's knowledge computable: website. URL: https://www.wolframalpha.com/about/ (viewed on January 12, 2020).

[20] Wolfram|Alpha computational intelligence : website. URL: https://www.wolframalpha.com/ (viewed on January 12, 2020).

[21] Curve Fitting \& Approximate Functions : website. URL: https://reference.wolfram.com/language/ guide/CurveFittingAndApproximateFunctions.html (viewed on January 12, 2020).

[22] Cubic Spline Interpolation versus Interpolating Polynomial : website. URL: https://demonstrations. wolfram.com/CubicSplineInterpolationVersusInterpolatingPolynomial/ (viewed on January 12, 2020).

[23] SageMath - Open-Source Mathematical Software System : website. URL: https://www.sagemath.org/ (viewed on January 12, 2020).

[24] SageMathCloud [Electronic resource] / SageMathCloud by SageMath, Inc. - 2016. - Access mode : https://cloud.sagemath.com/ (viewed on January 12, 2020).

[25] Univariate Polynomial Rings: website. URL: https://doc.sagemath.org/html/en/reference/ polynomial_rings/sage/rings/polynomial/polynomial_ring.html?highlight=lagrange\%20interpolation (viewed on January 12, 2020).

[26] Interpolation (scipy.interpolate) : website. URL: https://docs.scipy.org/doc/scipy/reference/ interpolate.html (viewed on January 12, 2020).

\section{References}

[1] Toffler A. (1971) Future Shock. New York: Bantam Books. 430 p. (in English)

[2] Knight P. (1996) Independent Study, independent studies and 'core skills' in higher education. The management of independent learning / eds. J. Tait, P. Knight. London: Kogan Page in association with SEDA. P.29-37. (in English)

[3] Bilousova L., Kolgatin O., Kolgatina L. (2019) Computer Simulation as a Method of Learning Research in Computational Mathematics. CEUR Workshop Proceedings. № 2393, P. 880-894. (in English)

[4] Ramskyi Yu. S., Rafalska M. V. (2012) Development of competencies of future teachers of informatics and mathematics in the field of modeling. Naukovyi chasopys NPU imeni M. P. Dragomanova. Seriia 2: Kompiuterno-oriientovani systemy navchannia. №12 (19). P. 117-127. (in Ukrainian)

[5] Rafalska M. V. (2017) Development of ict-competences of future teachers of mathematics and informatics in the context of teaching and learning numerical analysis. Naukovyi chasopys NPU imeni M. P. Drahomanova. Seriia 2: Kompiuterno-oriientovani systemy navchannia. № 19. P. 78-83. (in Ukrainian)

[6] Ruotsalainen L., Vuorinen M. (2012) Numerical methods with Sage. Tbilisi Mathematical Journal. Vol. 5, № 2, P. 101-119. doi:10.32513/tbilisi/1528768905. (in English)

[7] Popel M. V. (2016) Organization of teaching mathematical disciplines in SageMathCloud. Teoriia ta metodyka navchannia matematyky, fizyky, informatyky. Krivoy Rog. Vol. 14. № 1(38). P. 3-110. (in Ukrainian) 
[8] Shokaljuk S. V., Markova O. M., Semerikov S. O. (2017) SageMathCloud as the Learning Tool Cloud Technologies of the Computer-Based Studying Mathematics and Informatics Disciplines. Modeling in Education: Status. Problems. Perspectives: monograph / ed. В. М. Соловйова. Cherkasy. P. 130-142. (in Ukrainian)

[9] Nečesal P., Pospíšil J. (2012) Experience with teaching mathematics for engineers with the aid of Wolfram Alpha. Proceedings of the World Congress on Engineering and Computer Science: WCECS 2012, October 24-26. San Francisco, USA. vol. 1, P. 271-274. (in English)

[10] Zhaldak M. I., Goroshko Y. V, Vinnychenko E. F. (2015) Mathematics with a computer: the teacher's guide. Kyiv. 315 p. (in Ukrainian)

[11] National Research Council. (2004) Computer Science: Reflections on the Field, Reflections from the Field. Washington, DC: The National Academies Press. 216 p. doi: 10.17226/11106. (in English)

[12] Zhaldak M. I. (2015) Problems of fundamentalization of the content of teaching computer science disciplines in pedagogical universities. Naukovyi chasopys NPU imeni M. P. Dragomanova. Seriia №2: Kompiuterno-oriientovani systemy navchannia. № 17. P. 3-15. (in Ukrainian)

[13] Tucker A., Belford G. G. (2020) Computer science. Encyclopedia Britannica. URL: https://www.britannica.com/science/computer-science (viewed on January 12, 2020). (in English)

[14] Atkinson K. (2017) Numerical analysis. Encyclopedia Britannica. URL: https://www.britannica.com/ science/numerical-analysis (viewed on January 12, 2020). (in English)

[15] Liashenko B. M., Kryvonos O. M., Vakaliuk T.A. (2014) Calculation methods: educational-methodical manual. Zhytomyr. 228 p. (in Ukrainian)

[16] Vakulenko I. V. (2016) Management of students' independent work using information and communication technologies. Naukovyi chasopys NPU imeni M. P. Dragomanova. Seriia 2: Kompiuterno-oriientovani systemy navchannia. № 18 (25). P. 50-64. (in Ukrainian)

[17] Zhaldak M. I. (2016) Informatization of the educational process should help to deepen and broaden the knowledge base - basis of the creative activity of the future professionals. Naukovyi chasopys NPU imeni M. P. Dragomanova. Seriia 2: Kompiuterno-oriientovani systemy navchannia. № 18. P.3-6. (in Ukrainian)

[18] Conte S. D., de Boor C. (1980) Elementary Numerical Analysis: An Algorithmic Approach, McGrawHill, New York. 432 p. (in English)

[19] About Wolfram|Alpha. Making the world's knowledge computable: website. URL: https://www.wolframalpha.com/about/ (viewed on January 12, 2020). (in English)

[20] Wolfram|Alpha computational intelligence : website. URL: https://www.wolframalpha.com/ (viewed on January 12, 2020). (in English)

[21] Curve Fitting \& Approximate Functions : website. URL: https://reference.wolfram.com/language/guide/ CurveFittingAndApproximateFunctions.html (viewed on January 12, 2020). (in English)

[22] Cubic Spline Interpolation versus Interpolating Polynomial : website. URL: https://demonstrations. wolfram.com/ CubicSplineInterpolationVersusInterpolatingPolynomial/ (viewed on January 12, 2020). (in English)

[23] SageMath - Open-Source Mathematical Software System : website. URL: https://www.sagemath.org/ (viewed on January 12, 2020). (in English)

[24] SageMathCloud [Electronic resource] / SageMathCloud by SageMath, Inc. - 2016. - Access mode : https://cloud.sagemath.com/ (viewed on January 12, 2020). (in English)

[25] Univariate Polynomial Rings : website. URL: https://doc.sagemath.org/html/en/reference/ polynomial_rings/sage/rings/polynomial/polynomial_ring.html?highlight=lagrange\%20interpolation (viewed on January 12, 2020). (in English)

[26] Interpolation (scipy.interpolate) : website. URL: https://docs.scipy.org/doc/scipy/reference/ interpolate.html (viewed on January 12, 2020). (in English)

\section{Iryna V. Vakulenko}

\section{MANAGEMENT OF INDEPENDENT WORK OF PRE-SERVICE TEACHERS IN THE PROCESS OF TEACHING INFORMATICS WITH THE USE OF COMPUTER MATHEMATICS SYSTEMS}

Abstract. Students' independent work is the main and one of the important forms of organization of the educational process in higher education, and therefore requires special attention. On the other hand, the training of a specialist capable of independent professional self-improvement throughout life is a requirement of today's fast-changing informatized society. One of the methodological areas of studying students' independent work is research on its management. After all, the characteristics of students' independent work are their independence under the condition of indirect direction, operative and systematic control, educational and methodical support by the teacher. The paper is devoted to the research on didactic 
opportunities of using computer mathematics software in relation to the management of independent work of pre-service teachers in the process of teaching computer science, in particular numerical analysis. The following free software tools of high scientific and methodological popularity, both among domestic and foreign researchers, have been chosen for analysis: Gran1, Gran-2D solvers; Wolfram|Alpha computational knowledge system, SageMathCloud cloud-oriented computer mathematics system. In addition, the paper concerns the use of Python programming language, which is provides powerful tools for performing scientific and engineering calculations. Besides, there is presenting of the main areas of application of numerical analysis of the considered software and the methods, which are the basis of execution of some software commands. Features of students' independent work are considered by the example of training of numerical analysis course, that includes strong interdisciplinary communication and promotes creative and research skills of pre-service teachers. The paper also considers an example of solving the problem of function interpolation as one of the most common methods for polynomial approximation in the course of numerical analysis. The proposed software can be used at different stages of management of pre-service teachers' independent work in the process of teaching numerical analysis.

Keywords: students' independent work management, computer mathematics system, numerical analysis, Gran1, Gran-2D, Wolfram | Alpha, SageMathCloud, Python.

DOI 10.31392/NPU-nc.series 2.2020.22(29).26

УДК 373.5.016:004.4

Свгеній Вікторович Козолуп

студент 3-го курсу факультету інформатики Національний педагогічний університет імені М.П. Драгоманова ORCID ID: 0000-0002-9098-5602

18fi.ye.kozolup@std.npu.edu.ua

\section{РОЗРОБКА НАВЧАЛЬНО-ТРЕНУВАЛЬНОГО СЕРЕДОВИЩА ДЛЯ ВИВЧЕННЯ ОСНОВ ПРОГРАМУВАННЯ ДЛЯ УЧНІВ 6-7 КЛАСІВ ЗАКЛАДІВ ЗАГАЛЬНОЇ СЕРЕДНЬОЇ ОСВІТИ}

Анотація. В статті розглядається важливий розділ навчального курсу інформатики програмування. Навчання програмування розвиває пам'ять, логічне мислення, креативність, самоорганізованість, стійкість та інтелектуальні здібності. На разі кількість годин, передбачених навчальною програмою з інформатики на вивчення теми “Алгоритми та програми”, а також “Основи об’єктно-орієнтованого програмування” можна вважати більш ніж достатньою (від $30 \%$ до 50\% в залежності від класу). Тому за системного та виваженого підходу до навчання, після завершення школи кожен учень може мати базові знання з програмування, а також вміти їх застосовувати для розв'язування практичних задач, що виникають під час різних видів його діяльності. Разом з цим в допомозі вчителю та учню можуть стати різноманітні тренувальні середовища розробки, а також навчальні веб-ресурси та сайти. Для таких сучасних та простих мов, як, наприклад Рython, ïx iснує достатня кількість. Проте на жаль, наявні сервіси не зовсім придатні до використання в 6-7 класах під час вивчення теми “Алгоритми та програми”. Саме тому доцільним є розробити просте у використанні, але змістовно наповнене навчально-тренувальне середовище для вивчення основ програмування мовою Python в середній школі. Середовище PyLearn розроблено для спрощення адаптації учнів до правил написання програмного коду, а також його тестування. Використання такого підходу дозволяє максимальну частину навчального часу приділити саме розв'язуванню практичних задач, що надалі дозволить учневі тільки поглиблювати свої знання та в старших класах почати роботу над власним навчальним або науковим проектом з програмування.

В статті розглянуто короткий аналіз популярних програмних засобів для навчання програмування, а також описано принцип роботи 3 розробленим навчально-тренувальним середовищем PyLearn.

Ключові слова: об'єктно-орієнтоване програмування, мова програмування, середовище розробки програмного забезпечення, навчально-тренувальне середовище.

3 кожним роком все більшої популярності на уроках інформатики в закладах загальної середньої освіти набуває використання сучасних об'єктно-орієнтованих мов програмування. Здебільшого це обумовлене тим, що синтаксис таких мов досить простий у вивченні, а самі мови розроблені за об'єктно-орієнтованою парадигмою програмування, що в свою чергу набагато простіше в розумінні того, за яким принципом створюються та взаємопов’язані програмні об'єкти. 